\title{
Survey of Residual Pesticides in Various Fresh Fruit Crops: A Case Study
}

\author{
Afzal Qamar ${ }^{1 *}$, Rafiq Asi², Munawar Iqbal', \\ Arif Nazir $^{3 * *}$, Khalid Arif ${ }^{4}$ \\ ${ }^{1}$ Department of Chemistry, Govt. Postgraduate College Sammanabad, Faisalabad-Pakistan \\ ${ }^{2}$ National Institute of Agriculture Biology (NIAB), Faisalabad-Pakistan \\ ${ }^{3}$ Department of Chemistry, University of Lahore, Lahore-Pakistan \\ ${ }^{4}$ Department of Mathematics and Statistics, The University of Lahore, Lahore-Pakistan
}

Received: 18 March 2017

Accepted: 15 May 2017

\begin{abstract}
An in-vitro study was conducted to estimate the pesticidal residues in five types of fruits; melon, guava, orange, peach, and mango. Organochlorine, organophosphate, carbamates, and pyrethroids, along with other insecticidal residues, were detected. The collection of samples was carried out from farmland located in the indigenous soil of Faisalabad and Toba Tek Singh. The residual pesticides were extracted by single-phase extraction and then purified by the gel permeation chromatographic technique. The extracted residues were isolated and quantified by HPTLC method. The detected residues were in the range of $0.1-0.3 \mathrm{mg} \mathrm{kg}^{-1}$. The study demonstrated a high risk of ongoing contamination posed by uncontrolled applications of pesticides, which are needed to be overcome on the lines of sustainable management measures.
\end{abstract}

Keywords: pesticides, fruits, gel permeation, chromatography, extraction

\section{Introduction}

Fruits and vegetables are decent sources of numerous natural bioactives like vitamins, minerals, fiber, and antioxidants, but they are widely contaminated by pesticide applications [1]. Besides a number of initiatives launched in strengthening sustainable management measures, such contamination is still a growing concern worldwide [2]. The increased demand for agricultural productivity to meet the besetting challenges of food security is a major hurdle in overcoming this concern as the use of pesticides

*e-mail: qamarchemist@gmail.com

**e-mail: anmalik77@gmail.com is inevitable to curtail weed and pest infestations. The use of pesticides is a serious environmental issue such as contamination and agricultural commodities [3-19]. Fresh fruits are widely ingested to make up the deficiency of abundant of bioactive nutrients and dietary antioxidants. The intake of these contaminated moieties among humans is somewhat higher than that of other forms of life. Various potential hazards have been posed by the trace amounts of carbamate pesticides as they often inhibit the acetylcholineregulating liver enzyme acetylcholinesterase (AChE) [20]. Moreover, pyrithyroid generates reactive oxygen species (ROS) that may produce oxidative stress when they are metabolized in a living system [21]. Hence, investigations of accumulation, distribution, and speciation of these dietary contaminants have become brought forth the need 
Table 1. A survey of pesticide residue study in Pakistani fruits.

\begin{tabular}{|c|c|c|c|}
\hline Fruit & Type of residue & $\begin{array}{l}\text { Residue } \\
\text { contents } \\
\left(\mathrm{mg} \mathrm{kg}^{-1}\right)\end{array}$ & References \\
\hline \multirow{4}{*}{ Mango } & Methamadophos & 0.16 & \multirow{4}{*}[22]{} \\
\hline & Cypermethrin & 0.50 & \\
\hline & Dialdrin & 0.20 & \\
\hline & Methyl parathian & 0.15 & \\
\hline \multirow{2}{*}{ Guava } & Chlorpyrifos & 0.25 & \multirow{2}{*}[23]{} \\
\hline & Methyl parathion & 0.25 & \\
\hline \multirow{4}{*}{ Melon } & Bifenthrin & 0.06 & \multirow{4}{*}[24]{} \\
\hline & Carbofuran & 0.07 & \\
\hline & Cypermethrin & 0.07 & \\
\hline & Chlorpyrifos & 0.06 & \\
\hline \multirow{3}{*}{ Orange } & Endosulfan & 0 & \multirow{3}{*}[25]{} \\
\hline & Chlorpyrifos & 0 & \\
\hline & Cypermethrin & 0.14 & \\
\hline \multirow{2}{*}{ Peach } & Chlorpyrifos & 0.92 & \multirow{2}{*}[26]{} \\
\hline & Cypermethrin & 0 & \\
\hline
\end{tabular}

to rationalize health safety measures. A survey report on a scenario of pesticide or other toxic residue on fresh fruits in Pakistan is shown in Table 1.

Pesticide testing in foodstuffs has become challenging, and different techniques have been developed to investigate these residues. Among the analytical approaches, thin layer chromatography (TLC) is widely employed for the analysis of pesticide residues - especially in food products [27]. The development of high-performance thin-layer chromatography (HPTLC) is its improved version of higher resolution and sensitivity over TLC. The present work was designed to determine the presence of pesticide residues in various fruit varieties in the indigenous soil of the Faisalabad District and Toba Tek Singh by HPTLC method.

\section{Experimental}

Samples of selected five fruits - mango, guava, kinnow, melon, and peach - were collected randomly from different farmlands of four zones, namely Zone 1: Toba Tek Singh; Zone 2: Gojra; Zone 3: Samundari; and Zone 4: Pirmahel, and analyzed for various pesticide residues. For pesticide extraction, slight modification was made as per the method reported by Kadenczki et al. [28]. Solid-phase extraction was used for the cleanup and concentration of the sample analysis. Samples collected from selected areas were processed for extraction and analysis as precisely reported by Wang et al. [29]. Various protocols were employed according to the nature of pesticides present on the fruit samples for the estimation of pesticide concentration through TLC. Pre-coated silica gel 60 glass plate $(20 \times 20 \mathrm{~cm})$ was activated. TLC plates validated by various appropriate methods and sample were run to identify the concentration of unknown residues. The samples were spotted along with marker compounds and developed in a pre-saturated tank of ethyl acetate following the method of Afful et al. [30]. The method (aluminium oxide G incorporated with silver nitrate and UV exposition) is specific for the detection of halogen and several other compounds by following the method of Tiryaki and Aysal [31]. This method (enzyme inhibition with cow liver extract and $\beta$-naphthyl-acetate substrate) is very specific for the detection of phosphoric, thiophosphoric acid ester and carbamate pesticides in fruits as per the method of Katrolia et al. [32].

\section{Results and Discussion}

For the quantification of pesticide residues, validated TLC plates were employed for standard runs of each
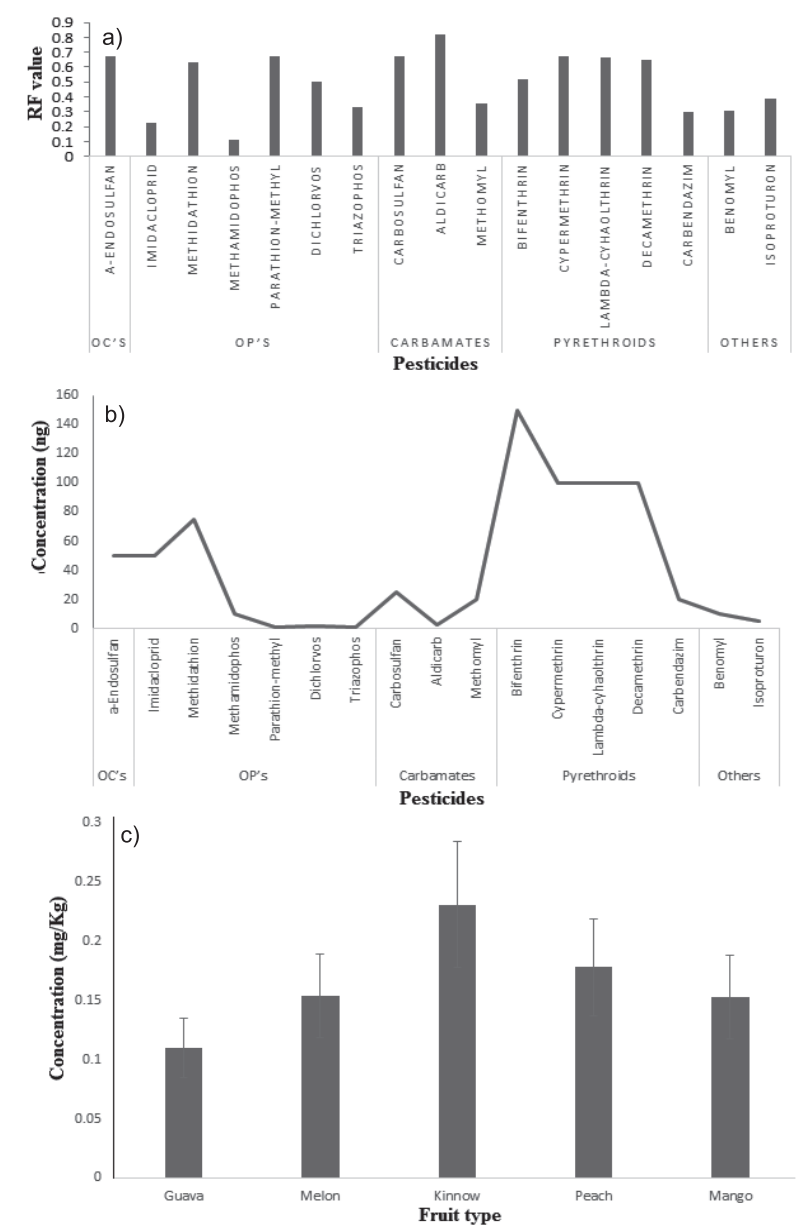

Fig. 1. a) RF values of different classes of pesticides on TLC plates, b) MDQ values, and c) organochlorine residues of different fruits.

RF: retardation factor; MDQ: minimum detectable quantity; ng: nanograms; OCs: organochlorines; OPs: organophosphates 
targeted residue. The detailed $\mathrm{Rf}$ values of each pesticidal residue are given in Fig. 1a). Similarly, minimum detectable quantity was measured for each chemical analogue and given in Fig. 1b). Fruit samples of different locations grown in the indigenous soil of zones 1-4 were analyzed for the estimation of pesticide residue. The permissible limits of organochlorine-based pesticide $\alpha$-endosulfan were $0.015 \mathrm{mg} \mathrm{kg}^{-1}$ and $0.0015 \mathrm{mg} \mathrm{kg}^{-1}$ for adults and children, respectively. We observed that high concentrations of $\alpha$-endosulfan were found in melon, kinnow, and peach, but only in very trace amounts in guava samples (Fig. 1c). Concentrations of $\alpha$-endosulfan were in the range of $0.068-0.108 \mathrm{mg} \mathrm{kg}^{-1}$, $0.074-0.153 \mathrm{mg} \mathrm{kg}^{-1}$, and $0.143 \mathrm{mg} \mathrm{kg}^{-1}$ for Zones $1-3$, respectively, while Zone 4 was found to be residue-free in mango samples. Moreover, its residual amounts noted in kinnow were $0.079-0.151 \mathrm{mg} \mathrm{kg}^{-1}, 0.068-0.231$, and 0.083 $\mathrm{mg} \mathrm{kg}^{-1}$ for Zones 1-3, respectively, with Zone 4 purged from this contamination in Pirmahel. The concentration of $\alpha$-endosulfan in peach was $0.072 \mathrm{mg} \mathrm{kg}^{-1}$ in Zone 4, which was absent for other fruit samples in this zone. A comparison of $\alpha$-endosulfan residue on different fruit samples showed that kinnow was highly contaminated, following peach and melon.

Five pesticide residues were observed on the basis of their $\mathrm{Rf}$ values in five varieties of selected fruit samples. Imidacloprid, a class of organophosphate residue, is a toxicant with chronic reference dose of $0.057 \mathrm{mg} \mathrm{kg}^{-1}$. Our study showed that reported samples have higher concentrations than permissible limits with residual amounts of $0.247-0.263 \mathrm{mg} \mathrm{kg}^{-1}$ in zone 1 and $0.257 \mathrm{mg} \mathrm{kg}^{-1}$ on average in Zone 2, while two sites were safe in this zone for peach samples. Moreover, peaches in Zone 4 were found to be contaminated with imidacloprid residues at $0.218 \mathrm{mg} \mathrm{kg}^{-1}$ on average in the pirmahel sector. Its concentration in melon was also higher than the allowed level, with $0.128 \mathrm{mg} \mathrm{kg}^{-1}$ in Zone 1, and the maximum amount was found in Zone 3 at $0.174 \mathrm{mg} \mathrm{kg}^{-1}$. Guava was found with marked contamination that surpassed the permissible limits. Zone 1 was a more contaminated area than other zones with $0.075-0.202 \mathrm{mg} \mathrm{kg}-1$ residue of imidacloprid. A brief comparison of imidacloprid and triazophos is given in Fig. 2a), which shows mango with highest residual contents while melon has the lowest.

Methidathion is also an organophosphorous residue, and its lowest acceptable quantity for chronic diseases is reported as $0.15 \mathrm{mg} \mathrm{kg}^{-1} /$ day. Our investigation showed that it has variable concentrations in various selected fruit samples that also zone dependently for each fruit. Residual contamination on guava was higher $\left(0.178-0.203 \mathrm{mg} \mathrm{kg}^{-1}\right)$ than permissible limits in Zone
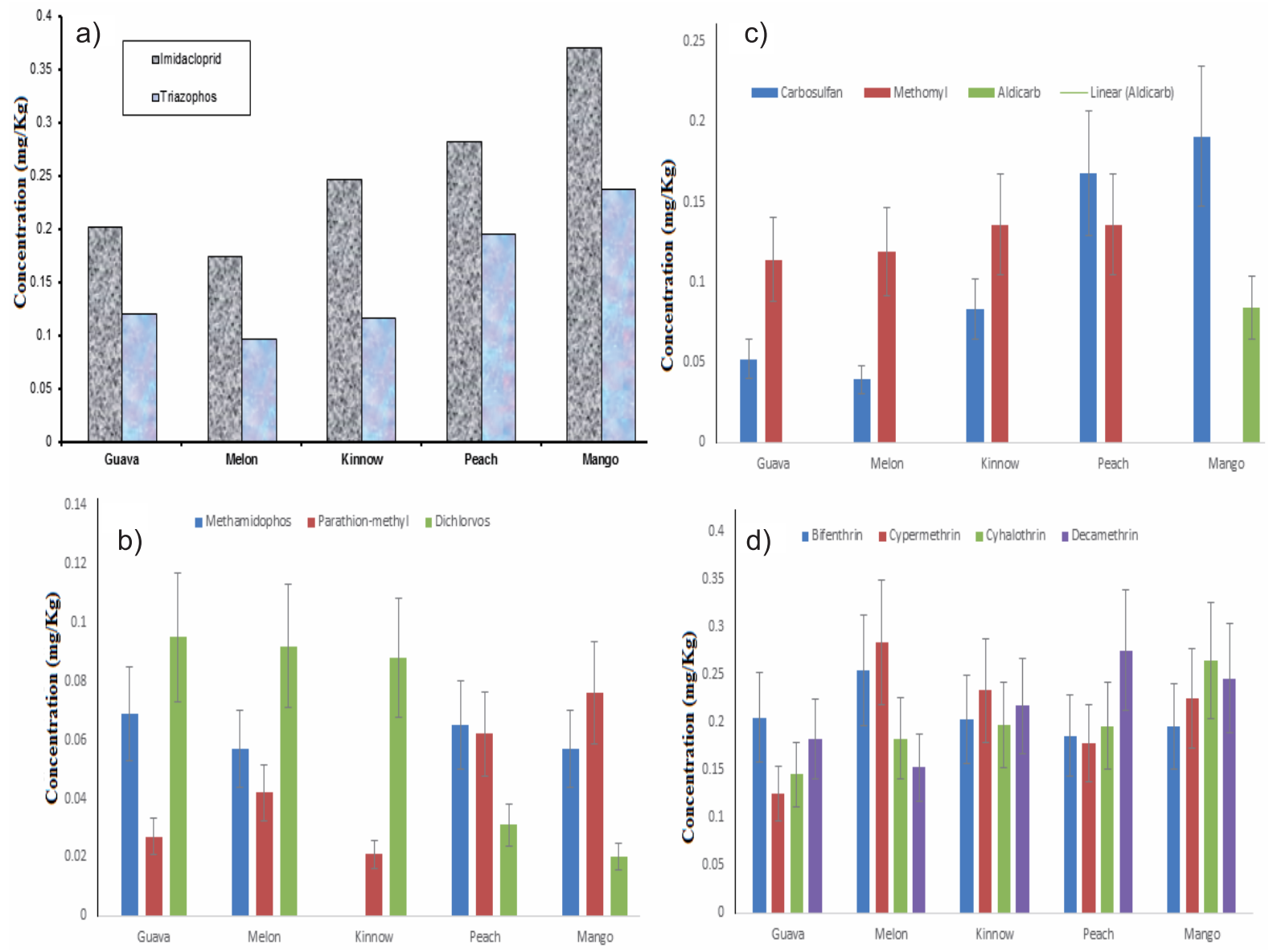

Fig. 2. a) Concentrations of imidacloprid and triazophos residues, b) concentrations of organophosphorus residue, c) concentrations of carbamate residues, and d) concentrations of pyrethroid residues on selected fruits. 
1, while guava in Zone 2 was found to be lower in contamination (0.087-0.095 $\left.\mathrm{mg} \mathrm{kg}^{-1}\right)$. Moreover, Zones 3 and 4 were also in safe ranges from this course. Similarly, its higher residual concentration was found in Zones 1 and 3, whereas Zones 2 and 4 were in safe limits for methidathion contamination on peaches. On the other hand, melon was found to be contaminated more than permissible limits of zone 1, while other tested zones remained under safe limits. For the mango samples, all zones except 4 contained more amounts of methidathion than safe limits.

Other contamination includes methamidophos, dichlorvos, and parathion-methyl of organophosphate, which were also found in these fruits as given in Fig. 2b). Dichlorvos and metamethamidophos were in higher amounts on guava samples, while mango samples contained maximum amounts of parathion-methyl among all other samples. Maximum residue limit (MRL) of dichlorvos was in the range of $0.02-2 \mathrm{mg} \mathrm{kg}^{-1}$. Our study showed that most of the zones investigated for indigenously grown selected fruit were within set limits for dichlorvos contamination - especially for mango fruit. For peach samples, 0.021-0.026 mg kg-1 as very close to safe limits and same trend was observed for other zones, also with subtle increases in contamination than permissible levels. On the other hand, kinnow and guava fruits contained more of this pesticide residue than the safe limit. Its highest amount $\left(0.088\right.$ and $\left.0.095 \mathrm{mg} \mathrm{kg}^{-1}\right)$ was observed in Zone 3, for kinnow and guava, respectively.

MRL for Triazophos was established at almost $0.02 \mathrm{mg} \mathrm{kg}^{-1}$ for the fruits. Our findings explored the unleashed use of this pesticide by observing its amounts that were more than permissible limits in different Faisalabad fruits. Zones 1 and 2 contained 0.027-0.095 and $0.089-0104 \mathrm{mg} \mathrm{kg} \mathrm{kg}^{-1}$ for guava fruit, but maximum residue was found on guava in Zone 3 at up to $0.120 \mathrm{mg} \mathrm{kg}^{-1}$, while Zone 4 was found to be safe from this curse of contamination. In the same way, other fruits in different zones were also found contaminated, but melons at most selected sites were substantially purged from this contamination.

Concentrations of organophosphate residues vary noticeably from fruit to fruit, but they were detected in almost all tested fruit samples, and the residue of methidathion were significant in guava $\left(0.203 \mathrm{mg} \mathrm{kg}^{-1}\right)$ and mango $\left(0.219 \mathrm{mg} \mathrm{kg}^{-1}\right)$ - irrespective of zones.

Carbamates are actually a urethane and an ester derivative of carbamic acid. They are mostly employed as a pesticide, but their unleashed application and consequent health concerns are associated with overlooked MRL levels as established by the U.S. Environmental Protection Agency. Carbosulfan and methomyl, recommended MRL 0.1 and $0.02 \mathrm{mg} \mathrm{kg}^{-1}$, respectively, were carbamates studied on selected fruit samples in four zones. Carbosulfan residue observed on melon was within safe limits, while mango samples of Zones 2-3 showed higher concentrations. Zone 1 of mango samples were below contamination for MRL levels. The same trend was observed in peach samples having maximum concentration of almost $0.16 \mathrm{mg} \mathrm{kg}^{-1}$ in Zones 2-3.

Another synthetic chemical, methomyl of the carbamates class, was also studied on sample fruits, and our investigation showed that almost all fruit samples had higher residual values than safe limits that varied by zone and fruit nature. The maximum value of methomyl was observed on peach and kinnow, with more or less $0.136 \mathrm{mg} \mathrm{kg}^{-1}$ in Zone 3. Moreover, mango also contained higher levels than MRL, but was comparatively lower in amount than in other fruits studied for selected areas, but the carbamate found for this fruit was aldicarb at MRL $0.3 \mathrm{mg} \mathrm{kg}^{-1}$, which was also quantified using the TLC method. Furthermore, it was observed that aldicarb was not detected in any tested samples in Zone 2, but it was detected only in mango collected from Zone 1. We observed that mango contained a maximum amount of carbosulfan, while kinnow was more contaminated with methomyl among all the fruit varieties analyzed (Fig. 2c).

Almost all tested samples were found to be contaminated with pyrethroid, but we observed that its concentrations varied from zone to zone and by fruit variety. Bifenthrin residue on mango was found to be higher than MRL $\left(0.1 \mathrm{mg} \mathrm{kg}^{-1}\right)$, especially in Zone 3 (in the range of $0.185-0.195 \mathrm{mg} \mathrm{kg}^{-1}$ ) than Zone 1, which demonstrated $0.157-0.183$ range of contamination. The maximum amount of bifenthrin was observed in melon unexpectedly in Zone 2 and Zone $4\left(0.25 \mathrm{mg} \mathrm{kg}^{-1}\right.$ on average) than Zone 1 with residual range 0.178$0.225 \mathrm{mg} \mathrm{kg}$. . Other pyrethroid contents, including cypermethrin, were also present in variable amounts, but mostly more than established MRL levels. Its maximum amount was observed on seasonal melon at $0.284 \mathrm{mg} \mathrm{kg}^{-1}$ in Zone 1 as compared to other zones that also contain residual concentrations higher than MRL but lower than in Zone 1. Cypermethrin on guava fruit remained almost the same in all zone with mere differences, but decamethrin on this fruit was not detected in most of the zones except for one site of Zone 1, which contained $0.182 \mathrm{mg} \mathrm{kg}^{-1}$, and another site of Zone 3 with traces of $0.081 \mathrm{mg} \mathrm{kg}^{-1}$ on average.

Detailed comparison of these residues among different fruits is given in Fig. 2d). It showed that cyhalothrin was found to be maximum on mango while melon contained maximum amounts of bifenthrin and cypermethrin compared to other fruit verities. Furthermore, the highest amount of decamethrin was noted on peach samples. Overall, higher residues of "thiophanate-methyl" were observed in orange and peach. Imidacloprid, methidathion, and triazopho residues were found to be higher in all fruit samples with the maximum concentration in mango (0.210-0.367 $\left.\mathrm{mg} \mathrm{kg}^{-1}\right)$, whereas guava and melon contained almost similar residues.

Fungicides and herbicides were also detected in all fruit samples collected from the control and effected areas in Faisalabad Division. Carbendazim and benomyl were found as fungicide residues, while only isoproturon was detected in fruit samples. The lowest concentration 
of fungicide and herbicide was determined in the control area, while substantial higher residues of fungicides and herbicide were calculated in the affected area. Carbendazim and benomyl residues were high in Jhang areas while isoproturon residues had the same baseline in all fruit samples of the control area. Pirmahal and Sumandari contained higher residues of carbendazim, and the least residue was found in Toba Tek Singh (TTS) and Gojra samples collected from the affected area. Thiophanate-methyl was also detected in mango samples and the highest concentration was found in TTS and Pirmahal (0.570 and $0.135 \mathrm{mg} \mathrm{kg}^{-1}$, respectively).

The obtained data was in close agreement with the results of Ambrus et al. [33], who used specific statistical and computational techniques to process method validations. Analysis of tested fruit samples showed remarkable pesticidal contamination. The concentrations of residual contents are largely linked with the level of humidity, range of temperature extremes, and some operational features of pesticidal applications, including dosage and dilution factor.

The pesticide residues found in fruits by using HPTLC methods are given below and contained maximum residual limits of the U.S. EPA, but most fruit samples collected from control and effected area showed more chlorpyriphos residue than the recommended limits $\left(0.05 \mathrm{mg} \mathrm{kg}^{-1}\right)$, which may be due to mismanagement or non-availability of proper information about pesticide applications. Determining organochlorines, organophosphates, carbamates, and pyrethroid pesticides in fruits and vegetables showed no interference after cleanup in a thin layer of chromatographic methods as reported earlier by Patil et al. [34]. The residual levels in fruit samples were below the maximum residue limits (MRL) of FAO/WHO and the U.S. EPA.

Carbendazim was detected in most of the fruits, and higher concentrations of this compound were detected in the affected areas of TT Singh, Gojra, and Pirmahal samples. High residues of carbendazim were found in guava samples as compared to others. Endosulfan was the only chlorinated residue found in fruit samples. Kinnow had higher residue contents of endosulfan than other fruits, but the lowest concentrations were detected in mango. Pyrethroids were detected frequently in fruit samples, and high residues of cypermethrin, bifenthrin, and cyhalothrin were found in all fruit samples of the affected area. Imidacloprid and methidathion were found in most fruit samples of the affected area, whereas dichlorvos residue was not so dominant in most fruit samples.

Before 2010 residual concentration was not in alarming situation on the fruits as well as other natural edibles. Tahir et al. [35] surveyed fruits and vegetables from the market of Lahore and showed that these commodities had safe limits lower than MRLs. Our results were consequently more alarming, drawing attention to the increase in pesticide residue with the passing of years, and are definitely a threat to the environment. The current investigation revealed that the fruits contain a significant amount of pesticides, which might be toxic to human beings and under the current scenario of environmental pollution [36-51]. This situation will become more alarming in coming years.

\section{Conclusions}

Consistent intentional use of pesticides and their ability to deleteriously impact other forms of life in addition to pest control raises significant concerns regarding food safety and human health. Unquestionably, crop yields have improved significantly through the application of pesticides by reducing losses induced by pests and insects. However, the loss of health and the disease burden related to the ingestion of residual pesticides is multiplied and comes out as a serious issue. The presence and continuous use of contaminated fruits is a threat to human as well as animal lives. The direct use of fruits from farm or orchard must be avoided due to the presence of high residual levels of synthetic pesticides.

\section{References}

1. AKHTAR S. Food safety challenges - a Pakistan's perspective. Critical reviews in food science and nutrition. $\mathbf{5 5}, 219,2015$.

2. SZPYRKA E., KURDZIEL A., MATYASZEK A., PODBIELSKA M., RUPAR J., SŁOWIK-BOROWIEC M. Evaluation of pesticide residues in fruits and vegetables from the region of south-eastern Poland. Food Control. 48, 137, 2015.

3. MREMA E.J., RUBINO F.M., BRAMBILLA G., MORETTO A., TSATSAKIS A.M., COLOSIO C. Persistent organochlorinated pesticides and mechanisms of their toxicity. Toxicology. 307, 74, 2013.

4. MORRIS A., MURRELL E.G., KLEIN T., NODEN B.H. Effect of two commercial herbicides on life history traits of a human disease vector, Aedes aegypti, in the laboratory setting. Ecotoxicology. 25, 5, 863, 2016.

5. ADAMCOVÁ D., VAVERKOVÁ M.D., STEJSKAL B., BROUSKOVA E. Household solid waste composition focusing on hazardous waste. Pol. J. Environ. Stud. 25, 2, 487, 2016.

6. CEMPEL M., NIKEL G. Nickel: a review of its sources and environmental toxicology. Pol. J. Environ. Stud. 15, 375, 2006.

7. DARGAHI A., GOLESTANIFAR H., DARVISHI P., KARAMI A., HASAN S.H., POORMOHAMMADI A., et al. An investigation and comparison of removing heavy metals (lead and chromium) from aqueous solutions using magnesium oxide nanoparticles. Pol. J. Environ. Stud.. 25, 2, 557, 2016.

8. DAUD M.K., HASSAN S., AZIZULLAH A., JAMIL M., REHAN N., IRUM R., QAISER MK, ZHU S-J. Physiological, biochemical, and genotoxic effects of wastewater on maize seedlings. Pol. J. Environ. Stud. 25, 2, 563, 2016.

9. GHANEM K.M., AL-GARNI S.M., AL-ZAHRANI M.A. Bioremediation of diesel fuel by fungal consortium using statistical experimental designs. Pol. J. Environ. Stud. 25, 1, 97, 2016.

10. GHASEMI M.K., YUSUFF R.B.M. Advantages and disadvantages of healthcare waste treatment and disposal 
alternatives: Malaysian scenario. Pol. J. Environ. Stud. 25, 1, 17, 2016.

11. HAI T., WEN-CHENG P., CHANG-FENG C., JIAN-PING X., WEN-JUN H. Remediation of acid mine drainage based on a novel coupled membrane-free microbial fuel cell with permeable reactive barrier system. Pol. J. Environ. Stud. 25, 1, 107, 2016.

12. HUSSAIN S., NAEEM M., CHAUDHRY M.N. Estimation of residual antibiotics in pharmaceutical effluents and their fate in affected areas. Pol. J. Environ. Stud. 25, 2, 607, 2016.

13. KALAJI H.M., SYTAR O., BRESTIC M., SAMBORSKA I.A., CETNER M.D., CARPENTIER C. Risk assessment of urban lake water quality based on in-situ cyanobacterial and total chlorophyll-a monitoring. Pol. J. Environ. Stud. 25, 2, 655, 2016.

14. KWAŚNY J., BALCERZAK W. Sorbents used for biogas desulfurization in the adsorption process. Pol. J. Environ. Stud. 25, 1, 37, 2016.

15. NIE F., ZHOU Y., LIU R., LIU Z., HUANG D. Pollutant removal and PCR-DGGE analysis of microbial community structural changes in an integrated vertical-flow constructed wetland. Pol. J. Environ. Stud. 25, 2, 709, 2016.

16. PALIULIS D. Removal of formaldehyde from synthetic wastewater using natural and modified zeolites. Pol. J. Environ. Stud. 25, 1, 251, 2016.

17. SZCZEPAŃSKA N., OWCZAREK K., KUDŁAK B., POKRYWKA A., MAZERSKA Z., GAŁUSZKA A., et al. Analysis and Bioanalysis: an Effective Tool for Data Collection of Environmental Conditions and Processes. Pol. J. Environ. Stud. 25, 1, 45, 2016.

18. TANEE T., SUDMOON R., THAMSENANUPAP P., CHAVEERACH A. Effect of Cadmium on DNA Changes in Ipomoea aquatica Forssk. Pol. J. Environ. Stud. 25, 1, 311, 2016.

19. TIAN F., LIU Y., LIU C., GU H., LIU H. Pollution status and multimedia fate simulation of phthalate acid esters (PAEs) in an arid city. Pol. J. Environ. Stud. 25, 1, 325, 2016.

20. SONG Y., CHEN J., SUN M., GONG C., SHEN Y., SONG Y., WANG L. A simple electrochemical biosensor based on AuNPs/MPS/Au electrode sensing layer for monitoring carbamate pesticides in real samples. J. Hazard. Mater. 304, 103, 2016.

21. KALE M., RATHORE N., JOHN S., BHATNAGAR D. Lipid peroxidative damage on pyrethroid exposure and alterations in antioxidant status in rat erythrocytes: a possible involvement of reactive oxygen species. Toxicol. lett. 105, 197, 1999.

22. HUSSAIN Z., SIDDIQUE S. Determination of pesticides in fruits and vegetables using acetonitrile extraction and GC/MS Technique. J Sci. Res. 40, 19, 2010.

23. PARVEEN Z., KHUHRO M., RAFIQ N., KAUSAR N. Evaluation of multiple pesticide residues in apple and citrus fruits, 1999-2001. Bull. Environ. Contam. Toxicol. 73, 312, 2004.

24. SHAFI M., IMRAN M., SARWAR M., KALSOOM S., MUJAHID H. A Study of Pesticide Residues in Different Fruits Collected from Different Fruit Markets of Lahore, Punjab. J. Agroalimen. Process. Technol. 20, 4, 298, 2014.

25. ANWAR T., AHMAD I., TAHIR S. Determination of pesticide residues in fruits of Nawabshah district, Sindh, Pakistan. Pak J Bot. 43, 1133, 2011.

26. ATA S., WATTOO F.H., FEROZ M., WATTOO M.H.S., TIRMIZI S.A., ASAD M.J. Analytical investigation of selected pesticide residues from fruits and vegetables by an improved extraction method using reverse phase High
Performance Liquid Chromatograph. Ethiopian J. Environ. Stud. Manage. 6, 342, 2013.

27. SHARMA D., NAGPAL A., PAKADE Y.B., KATNORIA J.K. Analytical methods for estimation of organophosphorus pesticide residues in fruits and vegetables: A review. Talanta. 82, 1077, 2010

28. KADENCZKI L., ARPAD Z., GARDI I., AMBRUS A., GYORFI L., REESE G., EBING W. Column extraction of residues of several pesticides from fruits and vegetables: a simple multiresidue analysis method. J. AOAC Int. 75, 53, 1992.

29. WANG P., YANG X., WANG J., CUI J., DONG A.J., ZHAO H.T., ZHANG L.W., WANG Z.Y., XU R.B., LI W.J., ZHANG Y.C., ZHANG H., JING J. Multi-residue method for determination of seven neonicotinoid insecticides in grains using dispersive solid-phase extraction and dispersive liquid-liquid micro-extraction by high performance liquid chromatography. Food Chem. 134, 1691, 2012.

30. AFFUL S., DOGBE S., AHMAD K., EWUSIE T. Thin Layer chromatographic analyses of pesticides in a soil ecosystem. West African Journal of Applied Ecology. 14, 1, 2009.

31. TIRYAKI O., AYSAL P. Applicability of TLC in multiresidue methods for the determination of pesticides in wheat grain. Bull. Environ. Contam. Toxicol. 75, 1143, 2005.

32. KATROLIA S., MEHROTRA R., RAMANUJAM S. Thin Layer Chromatography of Pesticides and Their Residues. Def. Sci. J. 24, 113, 2014.

33. AMBRUS A., FÜZESI I., SUSAN M., DOBI D., LANTOS J., ZAKAR F., KORSOS I., OLAH J., BEKE B.B., KATAVICS L. A cost-effective screening method for pesticide residue analysis in fruits, vegetables, and cereal grains. J. Environ. Sci. Health. 40, 297, 2005.

34. PATIL A., IKENOUE Y., WUDL F., HEEGER A. Water soluble conducting polymers. J. Am. Chem. Soc. 109, 1858, 1987.

35. TAHIR M.U., NAIK S.I., REHMAN S., SHAHZAD M. A quantitative analysis for the toxic pesticide residues in marketed fruits and vegetables in Lahore, Pakistan. Biomedica. 25, 171, 2009.

36. BABARINDE A., OGUNDIPE K., SANGOSANYA K.T., AKINTOLA B.D., ELIZABETH HASSAN A-O. Comparative study on the biosorption of $\mathrm{Pb}$ (II), $\mathrm{Cd}(\mathrm{II})$ and $\mathrm{Zn}(\mathrm{II})$ using Lemon grass (Cymbopogon citratus): kinetics, isotherms and thermodynamics. Chem. Int. 2, 89, 2016.

37. BABARINDE A., ONYIAOCHA G.O. Equilibrium sorption of divalent metal ions onto groundnut (Arachis hypogaea) shell: kinetics, isotherm and thermodynamics. Chem. Int. 2, 37, 2016.

38. BENABDALLAH N.K., HARRACHE D., MIR A., DE L.A., GUARDIA M., BENHACHEM F-Z. Bioaccumulation of trace metals by red alga Corallina elongata in the coast of Beni Saf, west coast, Algeria. . Chem. Int. 3, 220, 2017.

39. ENGIDA A.M., CHANDRAVANSHI B.S. Assessment of heavy metals in tobacco of cigarettes commonly sold in Ethiopia. . Chem. Int. 3, 213, 2017.

40. JAFARINEJAD S. Control and treatment of sulfur compounds specially sulfur oxides (SOx) emissions from the petroleum industry: a review. Chem. Int. 2, 242, 2016.

41. JAFARINEJAD S. Recent developments in the application of sequencing batch reactor (SBR) technology for the petroleum industry wastewater treatment. Chem. Int. 3 (3), 241, 2017.

42. MAJOLAGBE A.O., ADEYI A.A., OSIBANJO O. Vulnerability assessment of groundwater pollution in the vicinity of an active dumpsite (Olusosun), Lagos, Nigeria. Chem. Int. 2, 232, 2016. 
43. MAJOLAGBE A.O., ADEYI A.A., OSIBANJO O., ADAMS A.O., OJURI O.O. Pollution vulnerability and health risk assessment of groundwater around an engineering Landfill in Lagos, Nigeria. Chem. Int. 3, 58, 2017.

44. OGUNDIPE K.D., BABARINDE A. Comparative study on batch equilibrium biosorption of $\mathrm{Cd}(\mathrm{II}), \mathrm{Pb}$ (II) and $\mathrm{Zn}$ (II) using plantain (Musa paradisiaca) flower: kinetics, isotherm, and thermodynamics. . Chem. Int. 3, 135, 2017.

45. UKPAKA C. Predictive model on the effect of restrictor on transfer function parameters on pneumatic control system. Chem. Int. 2, 128, 2016.

46. UKPAKA C., IZONOWEI T. Model Prediction on the Reliability of Fixed Bed Reactor for Ammonia Production. Chem. Int. 3, 46, 2017.

47. UKPAKA C.P., IGWE F.U. Modeling of the velocity profile of a bioreactor: the concept of biochemical process. . Chem. Int. 3, 258, 2017.
48. IQBAL M. Vicia faba bioassay for environmental toxicity monitoring: a review. Chemosphere.144, 785, 2016.

49. IQBAL M., BHATTI I.A. Gamma radiation/ $\mathrm{H}_{2} \mathrm{O}_{2}$ treatment of a nonylphenol ethoxylates: degradation, cytotoxicity, and mutagenicity evaluation. Journal of hazardous materials. 299, 351, 2015.

50. IQBAL M., NISAR J., ADIL M., ABBAS M., RIAZ M., TAHIR M.A., YOUNUS M., SHAHID M. Mutagenicity and cytotoxicity evaluation of photo-catalytically treated petroleum refinery wastewater using an array of bioassays. Chemosphere.168, 590, 2017.

51. DU H., YU M., SUN J., SONG G., LI Y. Epidemiological Evidence of the Effects of Environmental Pollution on Male Reproductive Health in an Electronic Waste-Recycling Town. Pol. J. Environ. Stud. 25 (4), 1777, 2016. 